\title{
Degradation of methyl parathion by a soil bacterial isolate: A pot study
}

\author{
Archana Mishra ${ }^{1 *}$, Jamaluddin Khan², A. K. Pandey² \\ 'Department of Microbiology, DLSPG College, Bilaspur, Chhattisgarh, India, ${ }^{2}$ Department of Biological Sciences, Rani Durgawati \\ University, Pachpedi, Jabalpur, Madhya Pradesh, India
}

\author{
Received: 01-12-2016 \\ Accepted: 03-01-2017 \\ Published: 29-01-2017 \\ *Address for \\ correspondence: \\ Archana Mishra, Department \\ of Microbiology, DLSPG \\ College, Bilaspur, \\ Chhattisgarh, India. \\ Phone: +91-9826560597. \\ E-mail: archupandey_ggu@ \\ rediffmail.com
}

\begin{abstract}
The indiscriminate use of chemicals fertilizers and pesticides has not only deteriorated the environment but also the groundwater resources as well. Their intensive consumption causes deleterious effects on plant, animal, and aquatic ecosystems thereby causing serious problems related to health. Since these are one of the factors which are responsible for the contamination of air, water, and terrestrial ecosystems and also the cause of disruption of biogeochemical cycling, it is extremely important to bring down, the toxicity levels that these chemicals impose on the environment, by the use of effective technology, which is cost-effective and safe. It has been suggested that biodegradation becomes an attractive option for the destruction of pesticides since it utilizes a natural process and offers the potential for being cost-effective as well as safe technology. Thus, the present study deals with the isolation and use indigenous bacteria for degradation of an organophosphorus pesticide methyl parathion present in the soil samples which were collected from the pesticide contaminated agricultural field.
\end{abstract}

KEY WORDS: Biodegradation, bioremediation, gas chromatography, methyl parathion

\section{INTRODUCTION}

Environmental pollution has become the most important universal concern, due to the rapid growth of urbanization, industrialization, and use of modern agricultural productivity enhancers (pesticides, fertilizers, etc.). Pesticides usages are rigorous all over to control insect pests, millions of tons of pesticides are produced and used worldwide in close association with agriculture. The continuous and ignorant use of organophosphorus insecticides such as methyl parathion (MP) and methamidophos for the control of wide range of insects throughout the world have led to the potential neurotoxicity to the animal ecosystem. Consequently, this has led to serious concerns for the development of safe and convenient strategies to deal with its widespread dispersal in the atmosphere (Singh and Walker, 2006). Several conventional techniques are used for the detoxification of such toxic compounds, namely, incineration, landfilling, excavation but due to operational difficulties, treatment expenditure, the above-mentioned methods have met serious opposition. Degradation with the help of microbial flora is generally considered to be safe and effective technique for detoxification of such chemicals in a cost-effective way. Many amazing characteristics of microbes such as their small size, ubiquitous distribution, high specificity, surface area, potentially rapid growth rate, and unrivaled enzymatic and nutritional adaptability make them, as one of the most important recycling agents of pesticides in nature. Biodegradation is nothing but a metabolic process that involves the complete breakdown of an organic compound in the context of environmental sciences; it is defined as the use of biological agents to eliminate hazardous substances from the environment (Roe et al., 1998). There are two main approaches proposed for the bioremediation with microorganisms. In the first case, microorganisms can be applied directly to degrade pollutants and wastes in a reactor or in situ. In the second case, cell extracts or purified enzymes preparations of microbial origin could be used for decontamination purposes (Chapalamaduguru and Chaudhary, 1999). Direct application of microbes in contaminated sites for the remediation of toxic chemicals is a cheapest way of remediating the toxic compounds when conditions are favorable for the growth of microorganisms, but if the conditions are unfavorable, their growth would be very slow, and sometimes they die. In these conditions, the addition of nutrients plays a vital role in the bioremediation process that enhances the growth of microbes and ultimately the rate of biodegradation (Goldstein et al., 
1985). Pot studies are perhaps one of the most appropriate tests to access the potential of microbe, for degradation of pesticides including MP. Since the degradation efficiency of the test strain was analyzed previously in soil microcosm experiments, the study was taken forward from laboratory conditions to the field conditions, and thus the pot study was conducted. Indigenous bacterial strains were isolated from the soil samples which were contaminated with pesticides and screened for their potential in degrading the concerned pesticide.

\section{MATERIALS AND METHODS}

\section{Collection of Soil Samples}

Soil samples were collected from the fields which had a history of pesticide application of at least 10 years. After proper survey, the soil samples were collected from the agricultural field at, Jabalpur, Madhya Pradesh. Samples were taken randomly from a depth of 5 to $10 \mathrm{~cm}$ to minimize air contamination. Mandatory soil was taken by means of sterilized spatulas and collected in sterile polythene bags. The soil samples were then brought to the laboratory and maintained at $4^{\circ} \mathrm{C}$. The samples were then subjected to microbiological analysis.

\section{Isolation of MP Degrading Microbes: Enrichment Technique}

Enrichment technique was used for the isolation of MP degrading strain. $1 \mathrm{~g}$ of soil sample was taken and added to $50 \mathrm{ml}$ of minimal media (MM) which had the following composition $\mathrm{K}_{2} \mathrm{HPO}_{4}-5.8 \mathrm{~g} / \mathrm{L}$, $\mathrm{KH}_{2} \mathrm{PO}_{4}-4.5 \mathrm{~g} / \mathrm{L},\left(\mathrm{NH}_{4}\right){ }_{2} \mathrm{SO}_{4}-2 \mathrm{~g} / \mathrm{L}, \mathrm{MgCl}_{2}-0.16 \mathrm{~g} / \mathrm{L}$, $\mathrm{CaCl}_{2}-20 \mathrm{mg}, \mathrm{NaMoO}_{4}-2 \mathrm{mg}, \mathrm{FeSO}_{4}-1 \mathrm{mg}, \mathrm{MnCl}_{2}-1 \mathrm{mg}$ with $1 \mathrm{~g}$ glucose/L with 5 ppm MP (final concentration) and kept for incubation on a rotary shaker at $120 \mathrm{rpm}$ for $24 \mathrm{~h}$. After $24 \mathrm{~h}, 1 \mathrm{ml}$ of sample was taken and inoculated into fresh MM with stepwise increase in MP concentration. After the $4^{\text {th }}$ cycle of enrichment, $1 \mathrm{ml}$ broth culture was serially diluted and plated on nutrient agar plates and kept for incubation at $37^{\circ} \mathrm{C}$ for $24 \mathrm{~h}$. After $24 \mathrm{~h}$, selected colonies were picked and patched on nutrient agar plates with 50 ppm MP. Selected colonies were transferred on series of nutrient agar plates to obtain axenic culture. Only one strain was found to be potential MP degrader and thus was selected for future studies.

\section{Factors Affecting MP Utilization by the Test Bacterium}

\section{Effect of inoculum concentration on in vitro MP utilization}

To standardize the suitable inoculum concentration for maximum degradation of MP by the test strain, cell densities, namely, $1 \times 10^{5}, 1 \times 10^{6}, 1 \times 10^{7}$, $1 \times 10^{8}, 1 \times 10^{9} \mathrm{cfu} / \mathrm{ml}$ were added to the medium and incubated for 15 days at $35^{\circ} \mathrm{C}$. The degradation of MP was analyzed with the help of gas chromatography-mass spectrometry (GC-MS) (Labana et al., 2005).

\section{Effect of temperature on in vitro MP utilization}

To determine the effect of temperature on MP degradation, the cells of test strain $\left(1 \times 10^{5}\right)$ was added to different flasks with $5 \mathrm{ppm} \mathrm{MP}$ and incubated at various temperatures such as $15^{\circ} \mathrm{C}, 20^{\circ} \mathrm{C}, 25^{\circ} \mathrm{C}, 30^{\circ} \mathrm{C}, 35^{\circ} \mathrm{C}, 40^{\circ} \mathrm{C}, 45^{\circ} \mathrm{C}$, and $50^{\circ} \mathrm{C}$. All flasks were incubated for 15 days. The degradation of MP was analyzed with the help of GC-MS at various time intervals (Labana et al., 2005).

\section{Effect of hydrogen ion concentration on in vitro MP utilization}

To determine the optimum $\mathrm{pH}, \mathrm{MM}$ medium had $\mathrm{pH}$ values $(4,4.5,5,5.5,6,6.5,7,7.5,8,8.5,9,9.5,10)$ supplemented with $5 \mathrm{ppm}$ MP inoculated with cells of test strain $\left(1 \times 10^{5}\right)$ and incubated for 15 days. Degradation of MP was analyzed with the help of GC-MS at various time intervals (Labana, 2005).

\section{Effect of carbon source on in vitro MP utilization}

To select the best source of carbon, the carbon present in glucose was replaced by various sources of carbon (cellulose, raffinose, xylose, glucose sucrose) in MM, inoculated with cells of test strain $\left(1 \times 10^{5}\right)$ along with $5 \mathrm{ppm}$ MP. Inoculated flasks were incubated for 15 days at $35^{\circ} \mathrm{C}$. Samples were withdrawn at various time intervals and analyzed for degradation of MP with the help of GC-MS (Labana, 2005).

\section{Effect of nitrogen source on in vitro MP utilization}

To select the best source of nitrogen, the amount of nitrogen present in $\left(\mathrm{NH}_{4}\right)_{2} \mathrm{SO}_{2}$ was replaced with different sources of nitrogen $\left(\mathrm{NaNO}_{3}, \mathrm{NaNO}_{2}, \mathrm{KNO}_{3}, \mathrm{NH}_{4} \mathrm{CL}, \mathrm{NH}_{4} \mathrm{CO}_{3}\right)$ in $\mathrm{MM}$ and inoculated with cells of test strain $\left(1 \times 10^{5}\right)$ along with $5 \mathrm{ppm}$ MP. Inoculated flasks were incubated for 15 days at $35^{\circ} \mathrm{C}$. Samples were withdrawn at various time intervals and analyzed for degradation of MP with the help of GC-MS (Labana, 2005).

\section{Effect of incubation period on in vitro MP utilization}

To determine the effect of incubation period on degradation of MP under optimize condition of temperature and $\mathrm{pH}$, the flask containing MM and cells of test strain $\left(1 \times 10^{5}\right)$ along with $5 \mathrm{ppm} \mathrm{MP}$, were incubated at different time intervals. Samples were withdrawn at various time intervals and analyzed for degradation of MP with the help of GC-MS (Labana and Pandey, 2005; Kaiser, 1996; Richard et al., 2006). 


\section{Degradation of MP in Soil: A Pot Study}

The experimental setup was as follows: A completely randomized block was designed. Pots measuring $40 \mathrm{~cm}$ in length, top and bottom diameters of $40 \mathrm{~cm}$ and $15.2 \mathrm{~cm}$, respectively, were filled with $3 \mathrm{~kg}$ of soil to which MP was added exogenously. For this, air-dried soil was sieved ( $2 \mathrm{~mm}$ ) and aqueous solution of MP was added to the soil to form thick slurry. The final concentration of $\mathrm{MP}$ was $60 \mathrm{ppm}$. Cells of test strain were inoculated in the soil to obtain $1 \times 10^{5} \mathrm{cfu} / \mathrm{g}$ of soil. Simultaneously, the controls without the microbe were also maintained. The nitrogen and phosphorous sources were applied 1 week after the treatment of MP. The slurry was air dried at $40-45^{\circ} \mathrm{C}$ for 4 days, and the dried soil was pulverized before being used in the pots. These pots were then placed randomly in natural environmental condition. The moisture level in all the pots (control + experimental) was maintained throughout the period of an experiment by sprinkling tap water periodically whenever necessary. The pots were maintained at room temperature for 30 days (Labana et al., 2005).

\section{Extraction}

$1 \mathrm{~g}$ soil was withdrawn at various time intervals $(0,5$, $10,15,20,25,30$ days). $1 \mathrm{~g}$ soil was suspended in $10 \mathrm{ml}$ of $5 \% \mathrm{NaOH}$, vortexed for $10 \mathrm{~min}$ and centrifuged at $1500 \mathrm{rpm}$ for $10 \mathrm{~min}$. Supernatant was acidified to $\mathrm{pH} 2.0$ with HCL and extracted with double the volume of ethyl acetate. The aqueous phase was extracted again with ethyl acetate; both the extracts were pooled together and passed through anhydrous sodium sulfate to remove the traces of water. The filtrate was dried at room temperature and the residue was finally dissolved in $1 \mathrm{ml}$ of acetone and analyzed through GC-MS (Labana et al., 2005).

\section{RESULTS AND DISCUSSION}

A total 10 strains were isolated from the soil samples supplemented with MP. Out of these, six strains, namely, $\mathrm{C} 1, \mathrm{C} 2, \mathrm{C} 3, \mathrm{C} 6, \mathrm{C} 8$, and $\mathrm{C} 10$ which appeared in higher concentration were further screened for their ability to tolerate maximum concentration of MP. Thus, C1 was most potent strain, finally selected for further evaluation. Thus, on the basis of detailed biochemical test and 16s sequencing carried out with the help of a private company named "EUROFINS" Bengaluru, India, the bacterial isolate was identified as Achromobacter xylosoxidans.

Optimization of physiochemical conditions for maximizing the rate of MP degradation has given a considerable insight into the regulatory aspect of biodegradation. The ability of various bacteria for degradation of MP under different physiochemical conditions is not a general property but differs greatly under different growth conditions (Hanne et al., 1993; Kulkarni and Chaudhari, 2006). It also varies significantly not only at generic levels but also at strains level (Rani and Lalithakumari, 1994; Silva et al., 1999; Singh et al., 2003; Jain et al., 2005; Whitfield, 2005; Karpouzas and Singh, 2006; Ghosh et al., 2010; Abdel-Rahman et al., 2011). Thus, it cannot be generalized for all the bacterial strains and requires extensive standardization. The present study was conducted to determine the optimum conditions for rapid biodegradation of MP. It is evident from the data recorded in Figure 1 that the rate of degradation varied significantly with various concentrations of inoculum $\left(1 \times 10^{5}, 1 \times 10^{6}, 1 \times 10^{7}\right.$, $\left.1 \times 10^{8}, 1 \times 10^{9}\right)$. Maximum degradation was recorded in case of $A$.xylosoxidans when applied at $1 \times 10^{5} \mathrm{cfu} / \mathrm{ml}$. It was observed that the maximum percentage of pesticides degradation after 15 days was $89.23 \%$. It is evident from the data recorded in Figure 2 that the rate of MP degradation varied significantly with temperature. It was observed that degradation was gradually increased with temperature and reached its maximal at $35^{\circ} \mathrm{C} \pm 2{ }^{\circ} \mathrm{C}$ as evident by maximum MP degradation, but beyond this temperature, degradation was gradually declined. It was also observed that the isolated strain $A$. xylosoxidans \#C1 is a thermo-tolerant organism which was able to degrade MP at $35-50^{\circ} \mathrm{C} \pm 2$. Several other investigators have also reported similar observations with the bacterial

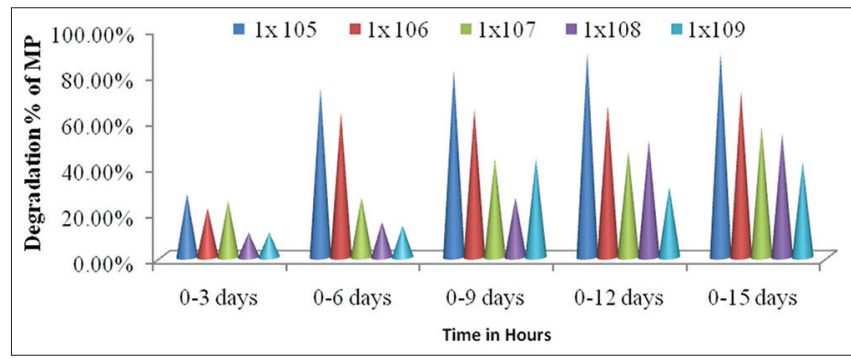

Figure 1: Effect of inoculum concentration on in vitro methyl parathion utilization by the test rain

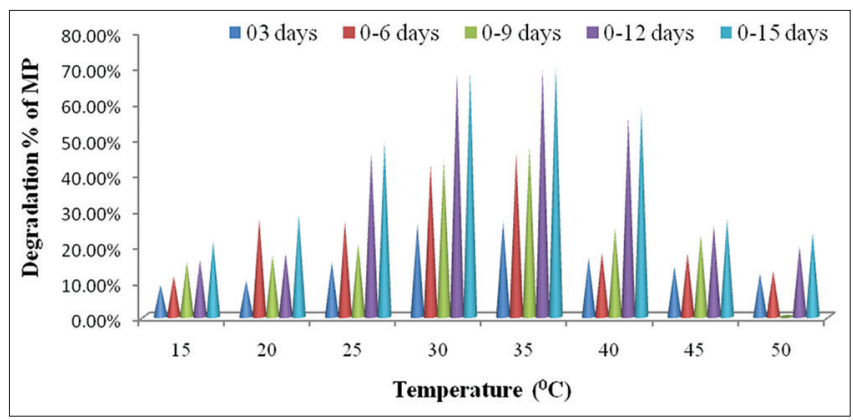

Figure 2: Effect of temperature on in vitro methyl parathion utilization by the test strain 
strains studied by them (Singh and Walker, 2006; Tognetti et al., 2007). It is clear from the data recorded in Figure 3 that the $\mathrm{pH} 6.5$ supported maximum degradation by the test strain after all days of incubation (9-15). However, it was observed that 7.5 and $8.0 \mathrm{pH}$ supported higher degradation at the initial stage which failed to support at a later stage. Similarly, the data recorded in Figure 4, shows that different types of carbon sources had a significant effect on the MP degradation by $A$. xylosoxidans \#C1. Better MP degradation was recorded in medium supplemented with glucose $(60.50 \%)$ after more or less at all the incubation. It was maximum after 15 days of incubation. It was followed by sucrose. Raffinose also supported the degradation of MP up to some extent. Several earlier workers have also reported glucose as one of the best carbon sources for rapid degradation of MP (Whitfield, 2005; Sánchez-Barragán et al., 2007). Data recorded Figure 5 clearly indicates that different types of $\mathrm{N}$ sources had a significant effect on degradation of MP by the test strain. Maximum MP degradation was recorded in $\mathrm{NH}_{4} \mathrm{Cl}$ after all the incubation and increased gradually. $\mathrm{KNO}_{3}$ and $\mathrm{NaNO}_{2}$ which supported MP utilization after 3 and 6 days of utilization respectively failed to support a later stage, i.e., 9-15 days of incubation where $\mathrm{NH}_{4} \mathrm{CO}_{3}$ induced better utilization of MP by the test strain. Similar observations have also reported by other investigators (Yadav et al., 2003; Sánchez-Barragán, 2007; Gavrilescu, 2005; Hussain et al., 2009; Díaz, 2004; Dua et al., 2002; Jokanovic and Prostran, 2009). Data recorded

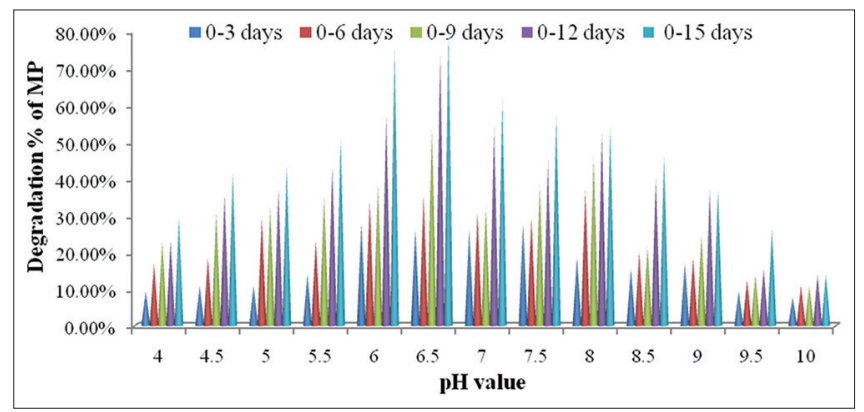

Figure 3: Effect of hydrogen ion concentration on in vitro methyl parathion utilization by the test strain

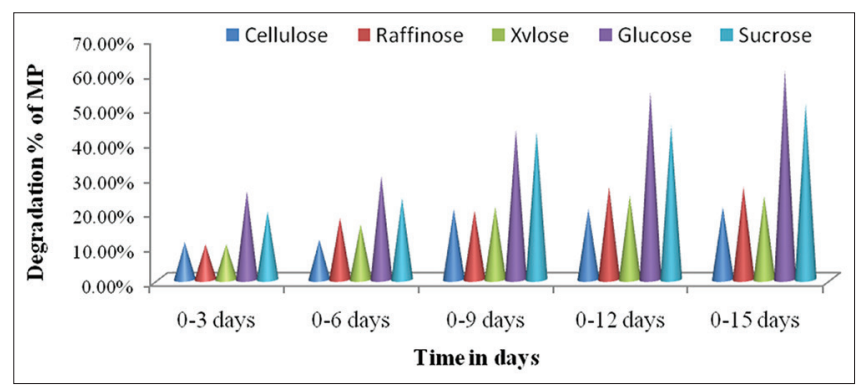

Figure 4: Effect of carbon sources on in vitro methyl parathion utilization by the test strain in Figure 6, clearly indicates biodegradation of MP varied significantly with the incubation period. It was gradually increased with incubation period and reached its maximal after 27 days of incubation. The rate of degradation was declined after 27 days of incubation. Therefore, on the basis of above discussion, it may be concluded the $35^{\circ} \mathrm{C}$, $6.5 \mathrm{pH}$ and 27 days of incubation are the best suitable condition for rapid degradation of MP by the test strain. After optimizing the growth conditions for maximum degradation of MP, pot studies were initiated. Pot studies are perhaps one of the most appropriate tests to access the potential of microbe for degradation of pesticides including MP. The pots were filled with $3 \mathrm{~kg}$ soil per pot with 60 ppm MP. Samples were withdrawn at various time intervals. After the extraction procedure, the samples were analyzed with the help of GC-MS. It is clear from the data recorded in Figures 7 and 8 and in Table 1 that the test bacterium (C1) was able to degrade the target

Table 1: Degradation $\%$ of MP in soil (0-30 days) by A. xylosoxidans \#Cl

\begin{tabular}{lcc}
\hline Incubation in days & Amount detected in sample $(\mathrm{ppm})$ & \% degradation \\
\hline $0-5$ & 0.016 & 11.11 \\
$0-10$ & 0.010 & 44.44 \\
$0-15$ & 0.007 & 61.11 \\
$0-20$ & 0.004 & 77.77 \\
$0-25$ & 0.002 & 88.88 \\
$0-30$ & 0.001 & 94.44 \\
SD & 0.0056 & 31.3592 \\
SEM & 0.0025 & 14.0242 \\
\hline
\end{tabular}

SD: Standard deviation, SEM: Standard error of mean, MP: Methyl parathion, A. xylosoxidans: Achromobacter xylosoxidans

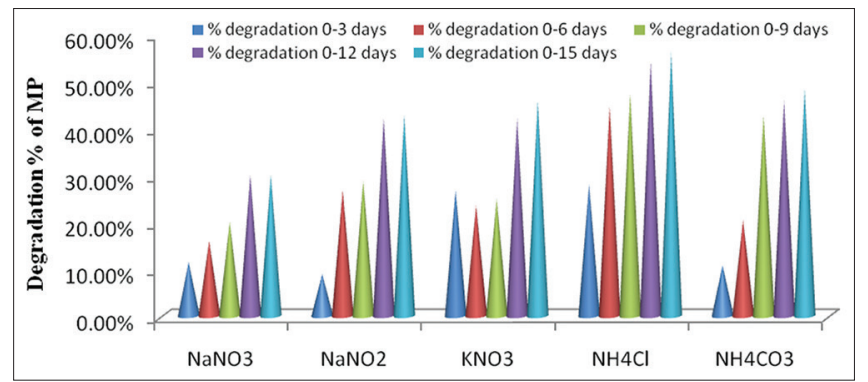

Figure 5: Effect of nitrogen sources on in vitro methyl parathion utilization by the test strain

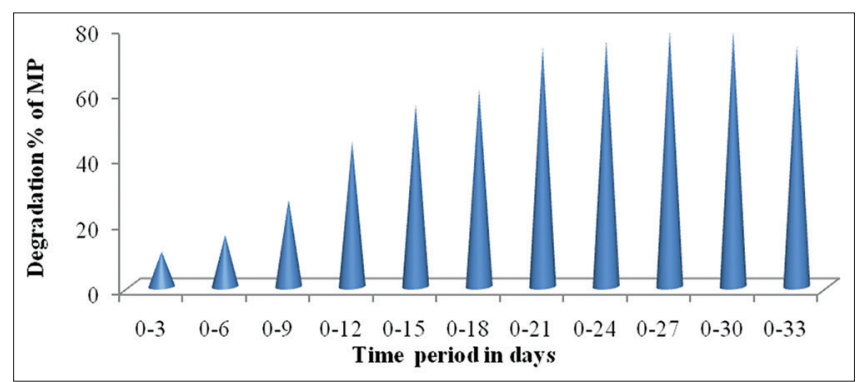

Figure 6: Effect of incubation period on in vitro methyl parathion utilization by test strain 


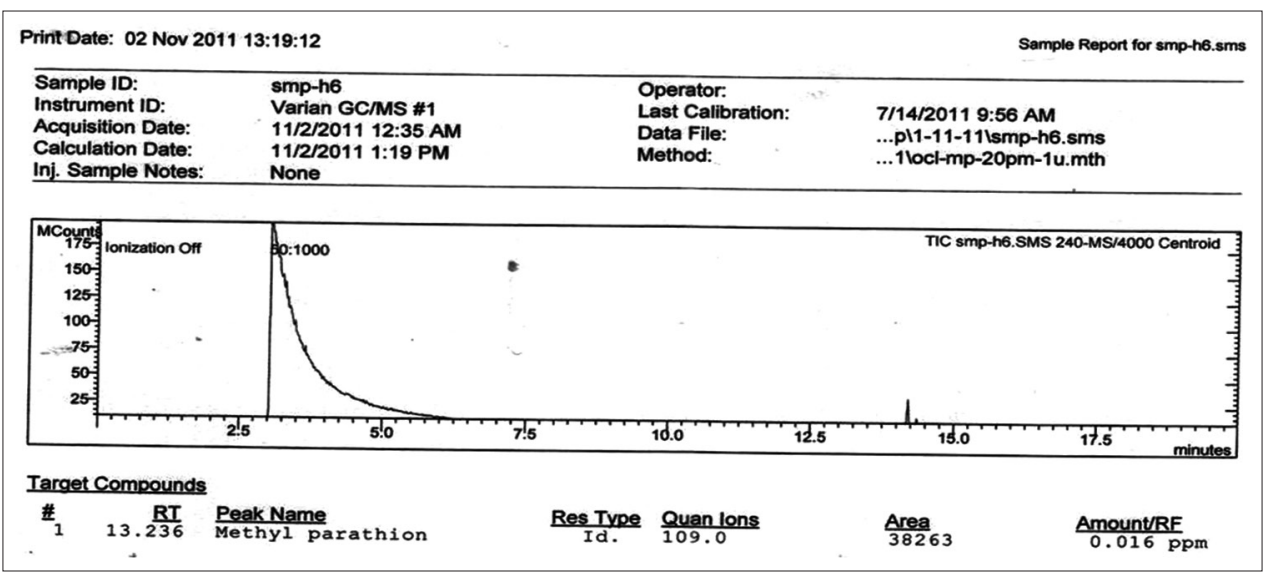

Figure 7: Detection of methyl parathion (ppm) on the 5th day of incubation in soil (pot study)

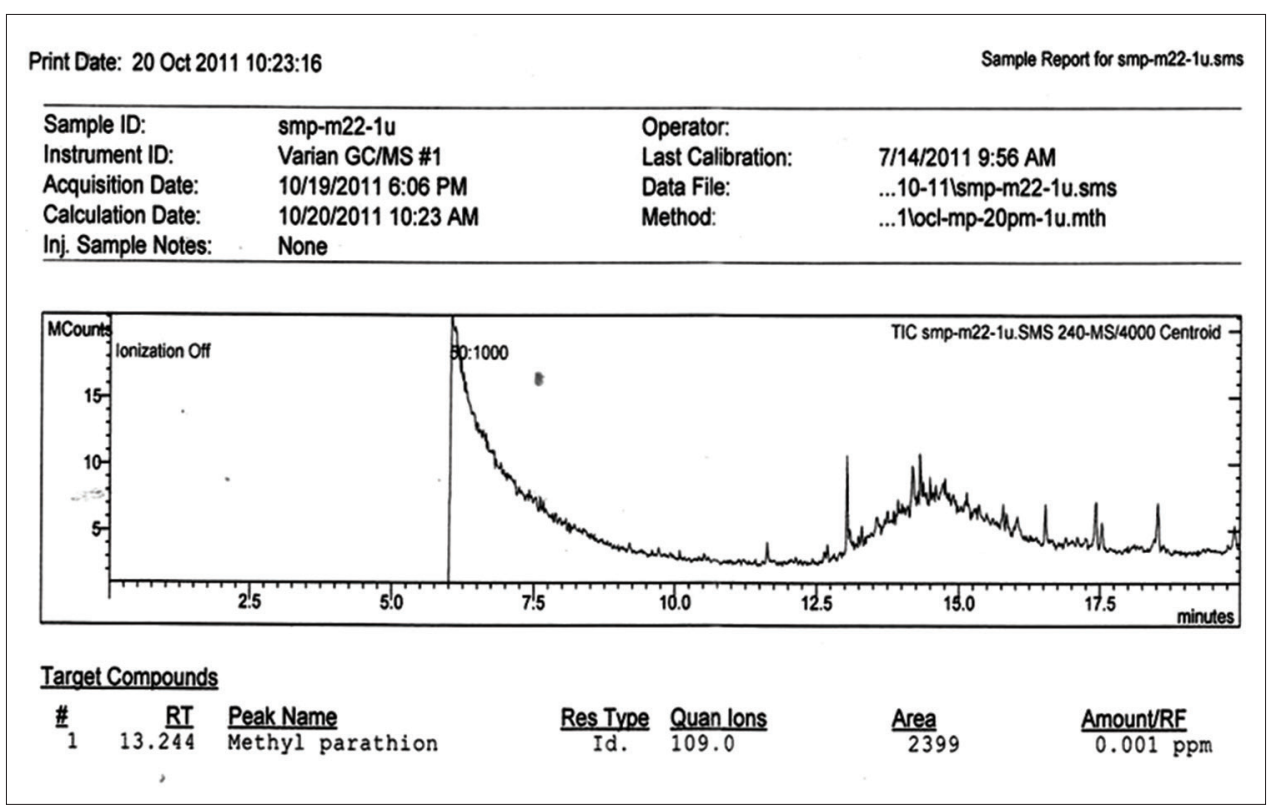

Figure 8: Detection of methyl parathion (ppm) on the 30th day of incubation in soil (pot study)

pesticide up to $94.44 \%$ after 30 days of incubation. Similar results were also obtained by Petersen et al. (1998), Sharma et al. (2003), Gopinath andTarnjis (2008). Labana et al. (2005) have reported pot, and field studies on bioremediation of p-nitrophenol (PNP) contaminated soil using Arthrobacter protophormiae RKJ100. Bioremediation of PNP was first carried out in pots using immobilized and free cells of the RKJ100 to ascertain the role of a suitable carrier material. They reported that the strain enhanced degradation on immobilization and the rate of PNP depletion decreased with increasing depth of soil. PNP was totally depleted in 5 days by immobilized cells whereas free cells were able to deplete $75 \%$ of PNP in the same period. Pakala et al. (2006) reported biodegradation of MP and PNP by a gram negative Serratia sp. strain DS001. The bacteria were capable of utilizing MP as a carbon source. They reported for the first time the existence of PNP hydroxylase component "A" typically found in gram-positive bacteria, in a gram-negative strain of the genus Serratia sp. Liu et al. (2007) reported biodegradation of MP by Acinotobacter radioresistens USTB-04. An initial concentration of $130 \mathrm{mg} / \mathrm{L}$ was completely biodegraded in $2 \mathrm{~h}$ in the presence of cell-free extract with a protein concentration of $148.0 \mathrm{mg} / \mathrm{L}$ which was increased with the increase of $\mathrm{pH}$ from 5 to 8 . Shen et al. (2010) reported degradation of MP by a Stenotrophomonas sp. SMSP-1. This strain could hydrolyze MP to PNP. Naqvi et al. (2011) reported similar observation in case of biodegradation of carbaryl in soil. Greeshma and Vasudevan (2013) reported the toxicity that these chemicals impose on the environment and the bioremediation of pesticides in agricultural soil. Hassan and Ahmed (2014) reported that different factors such as pesticide structure, pesticide concentration, soil types, soil moisture, $\mathrm{pH}$, temperature, 
salinity, organic matter, microbial flora, and microbial biomass have a significant effect on the degradative capacity of an organism. Kavita and Geeta (2014) reported the bioremediation and biodegradation of pesticide from contaminated soil and water. Similarly, Mahuddin and Fakhruddin (2014) reported degradation of diazinon - An organo-phosphorous pesticide by a bacterial isolate. Verma and Jaiswal (2014) reported the pesticide consequence and their microbial degradation in soil.

Thus, the present study is a model study that could be used for decontamination of sites contaminated with MP.

\section{CONCLUSION}

1. A total 10 strains were isolated from the soil samples supplemented with MP. Out of these, six strains, namely, C1, C2 , C3, C6, C8, and C10 which appeared in higher concentration were fur ther screened for their ability to tolerate maximum concentration of MP.Thus, C1 was most potent strain, finally selected for further evaluation

2. Different factors were optimized for maximum degradation of MP by the test strain (C1), such as inoculum concentration, temperature, $\mathrm{pH}$, different carbon sources, different nitrogen sources, and incubation period. It was recorded that maximum degradation was recorded when cells of bacterium $\mathrm{C} 1$ were applied at $1 \times 10^{5} \mathrm{cfu} / \mathrm{ml}$, at temperature $35^{\circ} \mathrm{C}$, at $6.5 \mathrm{pH}$.

3. It was recorded that utilization of MP was maximum when glucose was used as a carbon source and when $\mathrm{NH}_{4} \mathrm{Cl}$ was used as a nitrogen source.

4. It was seen that better degradation of MP was reported after 27 days of incubation.

5. When pot studies were conducted it was reported that, the test bacterium was able to degrade the target pesticide up to $94.44 \%$ after 30 days of incubation.

\section{ACKNOWLEDGMENT}

The authors are very thankful to the Director and Dr. Juwarkar (Chief Scientist), National Environmental Engineering Research Institute, Nagpur, Maharashtra, India, for providing all the laboratory and characterization facilities for the present work.

\section{REFERENCES}

Abdel-Rahman MA, Tashiro Y, Sonomoto K. Lactic acid production from lignocelluloses derived sugars using lactic acid bacteria: Overview and limits. J Biotechnol 2011;156:286-301.
Bastida F, Moreno JL, Hermandez T, Garcia C. The long term effects of management of a forest soil on its carbon content, microbial biomass, and activity under a semiarid climate. Appl Soil Ecol 2007;37:53-62.

Chapalamaduguru S, Chaudhary GR. Hydrolysis of carbaryl by a Pseudomonas sp. and construction of a microbial consortium that completely metabolizes carbaryl. Appl Environ Microbiol 1991;57:744-9.

Díaz E. Bacterial degradation of aromatic pollutants: a paradigm of metabolic versatility. Int Microbiol 2004;7:173-80.

Dua M, Singh A, Sethunathan N, Johri AK. Biotechnology and bioremediation: successes and limitations. Appl Microbiol Biotechnol 2002;59:143-52.

Gavrilescu M. Fate of pesticides in the environment and its bioremediation. Eng Life Sci 2005;5:497-526.

Goldstein RM, Mallory LM, Alexander M. Reasons for possible failure of inoculation to enhance biodegradation. Appl Environ Microbiol 1985;50:977-83.

Gopinath RB, Tarnjis MR. Water quality in health care. Int J Environ Technol Manage 2008;9:125-40.

Ghosh PG, Sawant NA, Patil SN, Aglave BA. Microbial biodegradation of organophosphorous pesticides. Int J Biotechnol and Biochem. 2010;5(6):871-876.

Greeshma O, Vasudevan N. Toxicity and bioremediation of pesticides in agricultural soil. Environ Sci Biotechnol 2013;12:421-44.

Hanne LF, Kirk LL, Apple SM, Narayan AD, Bains KK. Degradation and induction specificity in actinomycetes that degrade PNP. Appl Environ Micribiol 1993;59:3505-8.

Hassan S, Ahmed A. Factors controlling degradation of pesticides in soil. Agric Sci Dev 2014;3:273-8.

Hussain S, Siddique T, Arshad M, Saleem M. Bioremediation and phytoremediation of pesticides: Recent advances. Crit Rev Environ Sci Technol 2009;39:843-907.

Jain RK, Kapur M, Labana S, Lal B, Sarma PM, Bhattacharya D, et al. Microbial diversity. Curr Sci 2005;89:101-12.

Jokanovic M, Prostran M. Pyridinium oximes as cholinesterase reactivators. Structure-activity relationship and efficacy in the treatment of poisoning with organophosphorus compounds. Curr Med Chem 2009;16:2177-88.

Kaiser J. Pests over helm Bt cotton crop. Science 1996;273:423.

Karpouzas DG, Singh BK. Microbial degradation of organophosphorous xenobiotics: Metabolic pathways and molecular basis. Adv Microb Physiol 2006;15:119-225 .

Kavita R, Geeta D. Bioremediation and biodegradation of pesticides from contaminated soil and water - Anovel approach. Int J Curr Microboil Appl Sci 2014;3:23-33.

Kulkarni M, Chaudhari A. Biodegradation of p-nitrophenol by P. putida. Bioresour Technol 2006;97:982-8.

Labana S, Pandey G, Paul D, Sharma NK, Basu A, Jain RK. Pot and field studies on bioremediation of p-nitrophenol contaminated soil using Arthrobacter protophormiae RKJ100. 
Environ Sci Technol 2005;39:3330-7.

Liu FY, Hong MZ, Liu DM, Li YW, Shou PS, Yan H, et al. Biodegradation of methyl parathion by Acinetobacter radioresistens USTB-04. J Environ Sci (China) 2007;19:1257-60.

Mahuddin AA, Fakhruddin AN. Degradation of diazinon by bacterial isolate. Int J Biotechnol 2014;3:12-23.

Naqvi TA, Kanhar NA, Shar AH, Hussain M, Ahmed S. Microcosm studies for the biodegradation of carbaryl in soil. Pak J Bot 2011;43:1079-84.

Pakala SB, Garla P, Pinjari AB, Krovidi RK, Baru R, Yanamandra $\mathrm{M}$, et al. Biodegradation of methyl parathion and paranitro phenol: Evidence for the presence of para-nitro phenol-2-hydroxylase in a gram negative Serratia sp. Strain DS001. Appl Microbiol Biotechnol 2006;73:1452-62.

Petersen CJ, Tsao R, Coats JR. Glucosinolate aglucones and analogues: Insecticidal properties and a QSAR. Pestic Sci 1998;54:E35-42.

Rani NL, Lalithakumari D. Degradation of methyl parathion by Pseudomonas putida. Can J Microbiol 1994;40:1000-6.

Richard TL, Walker LP, Gossett M. Effects of oxygen on aerobic solid-state biodegradation kinetics. Biotechnol Prog 2006;22:60-9.

Roe RM, Hodgson E, Rose RL, Thompson DM, Devorshar $\mathrm{C}$, Anspaugh DD, et al. Basic principles and rationale for the use of insect genes in bioremidiation; Esterase phosphotriesterase cytochrome P450 and epoxide hydrolase. Rev Toxicol 1998;2:169-78.

Sánchez-Barragán I, Karim K, Costa-Fernándeza JM, Piletsky SA, Sanz-Medel A. A molecularly imprinted polymer for carbaryl determination in water. Sens Actuators B 2007;123:798-804.

Sharma V, Walia S, Kumar J, Nair MG, Parmar BS. An efficient method for the purification and characterization of nematicidal azadirachtins $\mathrm{A}, \mathrm{B}$, and $\mathrm{H}$, using MPLC and ESIMS. J Agric Food Chem 2003;51:3966-72.

Shen H, Ding G, Han G, Wang X, Xu X, Han J, et al. Distribution of PCDD/Fs, PCBs, PBDEs and organochlorine residues in children's blood from Zhejiang, China. Chemosphere 2010;80:170-5.

Silva FC, Cardeal ZL, DeCarvalho CR. Determination of organophosphorous pesticides in water using SPME-GC-MS. Quimica Nova 1999;22:197-200.

Singh BK, Walker A, Morgan JA, Wright DJ. Effects of soil pH on the biodegradation of chlorpyrifos and isolation of a chlorpyrifos-degrading bacterium. Appl Environ Microbiol 2003;69:5198-206.

Singh BK, Walker A. Microbial degradation of organophosphorus compounds. FEMS Microbiol Rev 2006;30:428-71.

Tognetti C, Mazzarino MJ, Laos F. Improving the quality of municipal organic waste compost. Bioresour Technol 2007;98:1067-76.

Verma JB, Jaiswal D. Pesticide relevance and their microbial degradation. Rev Environ Sci Biotechnol 2014;13:429-66.

Whitfield J. Biogeography. Is everything everywhere? Science 2005;310:960-1.

Yadav JS, Soellner MB, Loper JC, Mishra PK. Tandem cytochrome $\mathrm{P} 450$ monooxygenase genes and splice variants in the white rot fungus Phanerochaete chrysosporium: Cloning, sequence analysis and regulation of differential expression. Fungal Genet Biol 2003;38:10-21. 